NITOVSKA I.O. ${ }^{1}$, MORGUN B.V. ${ }^{1}$, ABRAIMOVA O.Ye. ${ }^{2}$, SATAROVA T.M. ${ }^{2}$

${ }^{1}$ Institute of Cell Biology and Genetic Engineering of the NAS of Ukraine,

Ukraine,03143,Kyiv, Akademika Zabolotnohostr., 148,e-mail:iranit@ukr.net,molgen@icbge.org.ua

${ }^{2}$ Institute of Grain Crops of the NAAS of Ukraine,

Ukraine, 49600, Dnipro, Volodymyra Vernadskoho str., 14, e-mail: satarova2008@ukr.net

凶iranit@ukr.net, (067) 598-44-03

\title{
GLYPHOSATE SELECTION OF MAIZE TRANSFORMANTS CONTAINING CP4EPSPS GENE
}

Aim. To study the selection conditions of maize transformants containing the CP4epsps gene using glyphosate as a selective agent. Methods. Tissue culture in vitro, Agrobacterium-mediated transformation, selection of transgenic plants, isolation of total plant DNA, analysis of plant DNA by polymerase chain reaction (PCR). Results. The morphogenic maize callus of immature embryos of the hybrid (PLS61)R $\mathrm{R}_{2} \times \mathrm{PLS} 61$ was produced, which had a high regeneration rate (up to $95 \%$ ), that persisted over long cultivation. Agrobacteriummediated transformation of the morphogenic callus and selection of the transgenic material using glyphosate yielded maize transformants containing the CP4epsps gene at a frequency of $1 \%$. Conclusions. Maize genotype (PLS61) $\mathrm{R}_{2} \times \mathrm{PLS} 61$ is promising for studies on the maize genetic transformation, in particular for the production of transgenic maize resistant to glyphosate herbicide. The use of morphogenic maize callus (PLS61) $\mathrm{R}_{2} \times$ PLS61 and glyphosate as a selective agent at a concentration of $0.1 \mathrm{mM}$ and $0.25 \mathrm{mM}$ in media for callusogenesis and $0.01 \mathrm{mM}$ in the medium for regeneration was effective for the selection of transgenic plants with the gene CP4epsps.

Keywords: Zea mays L., morphogenic callus, Agrobacterium-mediated transformation, PCR, genetic engineering.

Introduction. Maize (Zea mays L.) is one of the major world crops. It is sensitive to weeds in the early stages of growth, which can lead to significant yield losses of 30 to $90 \%$ with uncontrolled cultivation [1]. The chemical method of controlling weeds using herbicides is an effective complement to conventional methods and integral part of modern agriculture. Most of the currently available herbicides provide weed control only in a narrow range [2]. Glyphosate N-(phosphonomethyl)glycine) - is a systemic broad spectrum herbicide, the most common in the world to kill weeds, especially annual broadleaf weeds and grasses. Glyphosate inhibits the enzyme of the metabolic pathway of shikimic acid 5-enolpyruvylshikimate-3-phosphate synthase (EPSPS) blocking the biosynthesis of benzoid aromatic compounds, including essential amino acids (phenylalanine, tryptophan, threonine), causing the death of plants [3]. Obtaining transgenic plants resistant to herbicides, is one of the main areas the creation of biotech crops for agriculture [4]. One way of obtaining plants resistant to glyphosate, is the introduction of the mutant gene epsps, a product of which has a low affinity for glyphosate [5-7]. The CP4epsps gene is one such gene that was isolated from the Agrobacterium tumefaciens of the CP4 strain [8]. In a transgenic plant, it provides resistance to the herbicide, completely compensating for the function of the native plant enzyme EPSPS, and can be used as a selective marker gene $[5,6,9]$.

There is a natural variation in the sensitivity to glyphosate of maize different genotypes [10]. In this regard, to obtain glyphosate resistant plants, it is important to explore conditions for their selection on media with glyphosate. The aim of our study was to investigate the selection conditions for maize transformants of genotypes grown in Ukraine that would contain the CP4epsps gene using glyphosate as a selective agent.

\section{Materials and methods}

Plant material served maize morphogenic callus derived from immature embryos of hybrid $F_{1}$ $(\mathrm{PLS61}) \mathrm{R}_{2} \times \mathrm{PLS61}$ between somaclonal variant (PLS61) $\mathrm{R}_{2}$ of PLS61 line, conducted through in vitro culture, and line PLS61. Callus was obtained by culturing immature embryos in vitro on modified $\mathrm{N}_{6}$ medium [11] at $27^{\circ} \mathrm{C}$ in dark and maintained for 3 years, replanting to fresh nutrient medium every 3 weeks. To test the effect of different selective agents on the regeneration potential of the $(\mathrm{PLS} 61) \mathrm{R}_{2} \times \mathrm{PLS} 61$ callus, the following media were used: basic MSGR [9] containing $0.25 \mathrm{mg} / 16$ benzylaminopurine (BAP) (No. 1); medium No. 1

\footnotetext{
${ }^{\circ}$ NITOVSKA I.O., MORGUN B.V., ABRAIMOVA O.Ye., SATAROVA T.M.
} 
with the addition of $500 \mathrm{mg} / \mathrm{l}$ cefotaxime to inhibit the growth of agrobacteria (No. 2); medium No. 2 with the addition of $5 \mathrm{mg} / \mathrm{l}$ phosphinothricin (No. 3); medium No. 2 with the addition of 100 $\mathrm{mg} / \mathrm{l}$ of paromomycin (No. 4); medium No. 2 with the addition of $0.01 \mathrm{mM}$ glyphosate (No. 5). The calluses cultured in vitro in dark at $27^{\circ} \mathrm{C}$ were transferred to regenerative selective media No. 1-5 and cultured under light conditions with a photoperiod of $14 / 10 \mathrm{~h}$ at $25^{\circ} \mathrm{C}$ with replanting into fresh medium every 3 weeks. After 6 weeks, the effect of antibiotics and herbicides added to the base medium No. 1 on the greening and regenerative capacity of the callus was evaluated. A vector pCB135 [12], which was in A.tumefaciens strain GV3101, derived from strain C58 [13], was used for maize genetic transformation. The vector contained CP4epsps gene under control of the 35S RNA promoter of the cauliflower mosaic virus and $n p t$ II gene under the control of nopalinsyntase promoter. The growth media for A. tumefaciens containing the vector $\mathrm{pCB} 135$ was supplemented with $100 \mathrm{mg} / \mathrm{l} \mathrm{kanamycin}$ sulfate and $100 \mathrm{mg} / \mathrm{l}$ carbenicillin. The optical density of the bacterial suspension for transformation of explants (OD600) was adjusted to 0.4-0.5. A. tumefaciens preparation and Agrobacterium-mediated transformation of maize morphogenic callus were performed by the procedure [9]. After transformation, the calluses were transferred to a culture medium for callusogenesis, which contained macro-, microsalts, vitamins of the $\mathrm{N}_{6}$ medium [14], $30 \mathrm{~g} / \mathrm{l}$ sucrose, $3.5 \mathrm{mg} / \mathrm{l} \mathrm{AgNO}_{3}$, $1.0 \mathrm{mg} / 1$ dichlorophenoxyacetic acid $(2.4 \mathrm{D}), 0.5$ $\mathrm{mg} / \mathrm{l}$ dicamba, $0.1 \mathrm{mg} / \mathrm{l}$ abscisic acid, $7 \mathrm{~g} / \mathrm{l}$ agar, $500 \mathrm{mg} / \mathrm{l}$ cefotaxime and $0.1 \mathrm{mM}$ glyphosate and were cultured in dark at $27^{\circ} \mathrm{C}$. After two weeks, the calluses were planted in a fresh medium in which the glyphosate concentration was increased to 0.25 $\mathrm{mM}$ and grown under the same conditions for two weeks. Selected herbicide-resistant calluses were transplanted to selective regeneration medium No. 5 and grown under illumination at $24^{\circ} \mathrm{C}$ and a $16-$ hour photoperiod. After two weeks of cultivation, the calluses were transferred to a fresh selective regeneration medium and cultured for another two weeks under the same conditions. After two weeks of cultivation, the calluses were transferred to a fresh selective regeneration medium and cultured for another two weeks under the same conditions. Subsequently, the glyphosate-resistant green callus- es were transferred to regeneration medium No. 2 and continued cultivation, replanting the calluses to fresh medium every three weeks. The regenerating plants were separated from the callus and grown in jars containing bacteriostatic MS [15] without hormones, added $500 \mathrm{mg} / \mathrm{l}$ cefotaxime. The rooted plants were transferred to pots with soil and grown under standard greenhouse conditions.

Total DNA was extracted from regenerant leaves by the method using CTAB and PVP-40 [16]. Detection of CP4epsps and nptII gene sequences present in plant DNA was performed by PCR [12]. To exclude the possibility of contamination of plant material with agrobacteria, the amplification for bacterial vir-D1 gene was carried out. Transformation frequency was calculated as a percentage of the number of calluses that formed transgenic plants to the total number of calluses processed.

\section{Results and discussion}

Typically, calluses derived from immature embryos retain their regenerative capacity within 89 months of cultivation, and subsequently the callus regeneration activity attenuates [17]. We have isolated the genotype (PLS61) $\mathrm{R}_{2} \times$ PLS61 which calluses from immature embryos have retained their regenerative capacity for more than two years. The calluses obtained from the immature embryos of the $\mathrm{F}_{1}$ (PLS61) $\mathrm{R}_{2} \times \mathrm{PLS} 61$ hybrid have a regeneration frequency $(75 \%)$ higher than the original PLS61 calluses $(66.6 \%)$. Thus, the callus obtained from the hybrid line is promising for research on the genetic transformation of maize due to the high regenerative potential, which remains for a long cultivation.

To evaluate the effectiveness of different transgenic plant selection schemes after $(\mathrm{PLS61}) \mathrm{R}_{2} \times \mathrm{PLS} 61$ callus transformation, we tested the effect of additional constituents of selective media, namely, cefotaxime, paromomycin, phosphinothricin, and glyphosate on the regenerative potential of callus (Table 1, Fig. 1).

Adding to the medium of cefotaxime at a concentration of $500 \mathrm{mg} / \mathrm{ml}$ had no negative effect on the regenerative capacity of the callus. On the contrary, the rate of regeneration increased from $75 \%$ in the control to $94.4 \%$. Paromomycin at a concentration of $100 \mathrm{mg} / \mathrm{l}$ had a slight inhibitory effect on the morphogenetic potential of the callus (Table 1, No. 4). 
Table 1 . Effects on the regenerative capacity and greening of maize (PLS61) $\mathrm{R}_{2} \times$ PLS61 calluses by different selective agents

\begin{tabular}{|c|c|c|c|c|c|}
\hline Medium, No. & Planted calluses, & \multicolumn{2}{|c|}{ Calluses that formed shoots } & \multicolumn{2}{c|}{ Green calluses } \\
\cline { 3 - 6 } & pcs. & pcs. & $\%$ & pcs. & $\%$ \\
\hline 1 & 20 & 15 & 75.0 & 17 & 85.0 \\
\hline 2 & 18 & 17 & 94.4 & 17 & 94.4 \\
\hline 3 & 20 & 0 & 0 & 4 & 20.0 \\
\hline 4 & 19 & 13 & 68.4 & 14 & 73.7 \\
\hline 5 & 28 & 3 & 10.7 & 7 & 25.0 \\
\hline
\end{tabular}

Therefore, its use in transgenic plant breeding schemes can lead to the large number of "false" transformants that we had seen previously [12] and, consequently, the expense of effort, time, money to maintain, grow and analyze them. Paromomycin concentration of $100 \mathrm{mg} / \mathrm{l}$ was taken based on the results of other researchers [9], but for this genotype, the use of paramomycin at such a concentration may not be effective for transgenic plants selection. The use of $5 \mathrm{mg} / \mathrm{l}$ phosphinothricin in selective medium completely suppressed regenerative ability of callus (Fig. 1). When using glyphosate at a concentration of $0.01 \mathrm{mM}$ as a selective agent we observed the regeneration of shoots from three calluses (Fig. 1). However, shoots were mostly disco- lored, and those that looked green were subsequently discolored during further cultivation for the next 6 weeks. Therefore, glyphosate at a concentration of $0.01 \mathrm{mM}$ had a negative effect on the regenerative capacity of the maize callus. Cultivation of the maize callus for 5-6 weeks on regeneration medium, which contained $0.01 \mathrm{mM}$ glyphosate followed by cultivation during the same period in the absence of herbicide, did not lead to full plant recovery, indicating that this concentration of glyphosate was sufficient for transgenic plant selection.

Four hundred and eight (PLS61) $\mathrm{R}_{2} \times$ PLS61 hybrid calluses were processed by Agrobacteriummediated transformation (Table 2, Fig. 1).

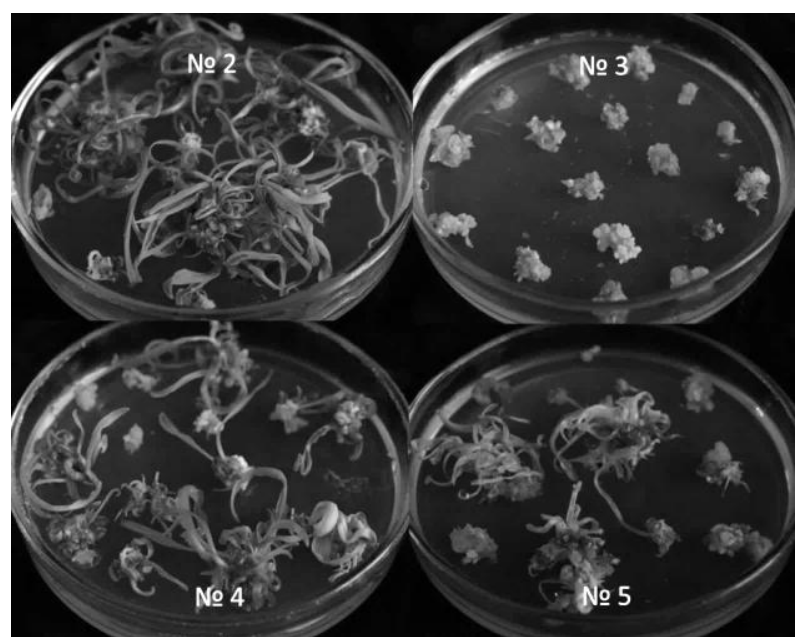

Fig. 1. Appearance of hybrid (PLS61)R ${ }_{2} \times$ PLS61 calluses after cultivation on selective regeneration media No. 25 for 6 weeks.

Table 2. Results on Agrobacterium-mediated transformation of (PLS61) $\mathrm{R}_{2} \times \mathrm{PLS} 61$ maize callus using pCB135 vector

\begin{tabular}{|c|c|c|c|c|c|c|c|c|c|}
\hline \multicolumn{5}{|c|}{ Processed calluses } & \multirow{3}{*}{$\begin{array}{l}\text { Plants in } \\
\text { jars, pcs. }\end{array}$} & \multirow{3}{*}{$\begin{array}{l}\text { Plants in } \\
\text { soil, pcs. }\end{array}$} & \multicolumn{3}{|c|}{ PCR, samples } \\
\hline \multirow{2}{*}{$\begin{array}{l}\text { Total } \\
\text { pes. }\end{array}$} & \multicolumn{2}{|c|}{ SRM* } & \multicolumn{2}{|c|}{ Regeneration** } & & & \multirow[t]{2}{*}{ Total, pcs. } & \multicolumn{2}{|c|}{$\langle+\rangle * * * *$} \\
\hline & pcs. & $\%$ & pcs. & $\% * * *$ & & & & pes. & $\%$ \\
\hline 408 & 225 & 55.2 & 47 & 20.9 & 129 & 25 & 81 & 5 & 6.2 \\
\hline
\end{tabular}

Notes: * SRM - quantity of calluses transplanted to selective regeneration medium; ** - the number of calluses that formed plants; $* * *$ - in relation to the quantity of calluses transplanted to the selective regeneration medium; **** - the quantity of samples in which the amplicons of the expected length were observed. 
After transformation, multiple plant regeneration was observed on the glyphosate containing medium (Fig. 2). The regeneration frequency was $11.5 \%$

One hundred and twenty nine regenerants obtained after transformation using the vector pCB135 were planted into jars with MS medium containing $500 \mathrm{mg} / \mathrm{l}$ cefotaxime. Plants that formed roots were transferred into pots with soil and grown in greenhouse (Fig. 3). In total, 25 plants were planted in soil, representing $19.4 \%$ of all plants planted in jars.

Eighty-one DNA samples extracted from plant regenerants of 29 lines derived from 23 callus lines were analyzed by PCR method. In the study on presence of the CP4epsps and nptII genes, amplicons of the expected length were found in five DNA samples of regenerants obtained from four callus lines (Fig. 4, 5). PCR for the presence of the bacterial gene vir-D1 did not reveal contamination of these samples with bacterial DNA (Fig. 5).

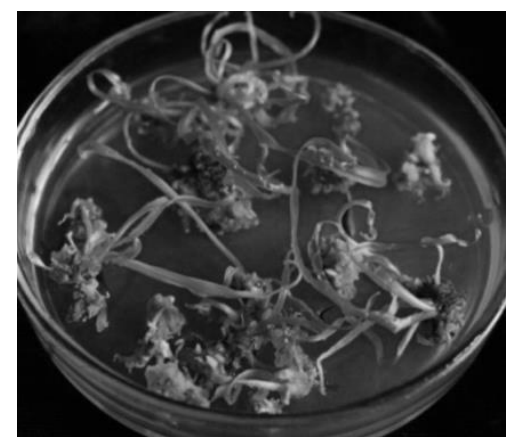

Fig. 2. (PLS61) $\mathrm{R}_{2} \times$ PLS61 plant regeneration after Agrobacterium-mediated transformation by vector $\mathrm{pCB} 135$ and carrying out selection using glyphosate.

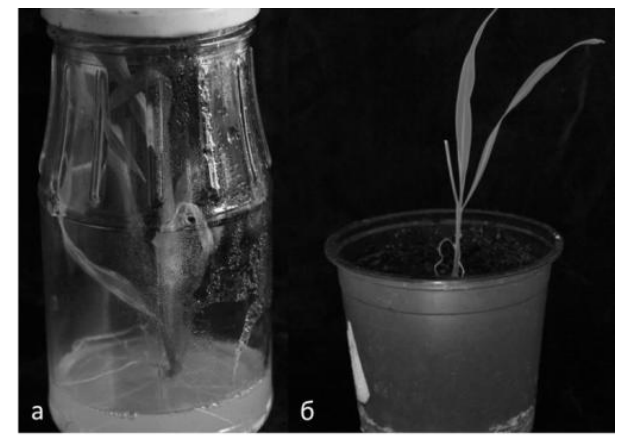

Fig. 3. Appearance of (PLS61) $\mathrm{R}_{2} \times \mathrm{PLS} 61$ maize plants in vitro (a) and in vivo (b) obtained after Agrobacteriummediated transformation using vector $\mathrm{pCB} 135$.

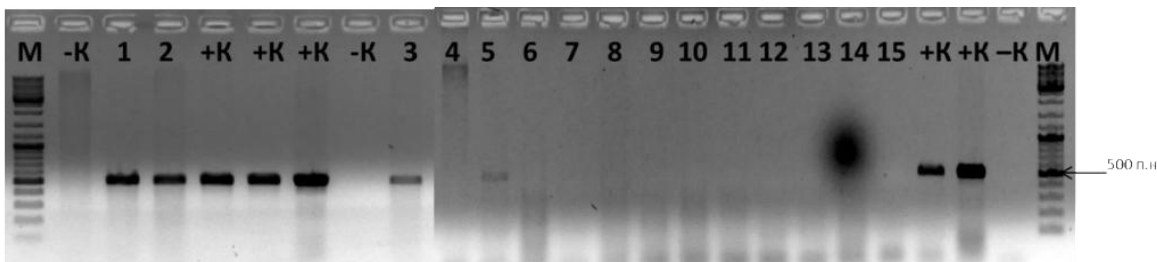

Fig. 4. Electrophoregram of products of plant DNA amplification of (PLS61) $\mathrm{R}_{2} \times \mathrm{PLS6} 1$ maize regenerants, obtained as a result of Agrobacterium-mediated transformation using vector pCB135 after PCR for the presence of the CPepsps transgene. The length of expected fragment was $498 \mathrm{bp}$. Lanes 1-15 - maize DNA samples: lane 1 - line 6 (regenerant from the Petri dish), 2 - 8 (regenerant from the dish), 3 - 9 (regenerant from the dish), 4 - 6-1-1 (greenhouse plant), $5-6-1$ (regenerant from the jar), $6-4-1$ (regenerant from the jar), $7-9-1$ (regenerant from the jar), $8-7-1$ (regenerant from the jar), $9-13-1$ ( regenerant from the jar), $10-13-1-1$ (regenerant from the jar), $11-6-4$ (regenerant from the jar), 12 - 1-2 (regenerant from the jar), $13-13-1-2$ (regenerant from the jar), 14 - 13-1-8 (regenerant from the jar), $15-7-1-3$ (regenerant from the jar); $+\mathrm{K}-$ positive control, $-\mathrm{K}-$ negative control, $\mathrm{M}-$ molecular weight marker Leader Mix. 


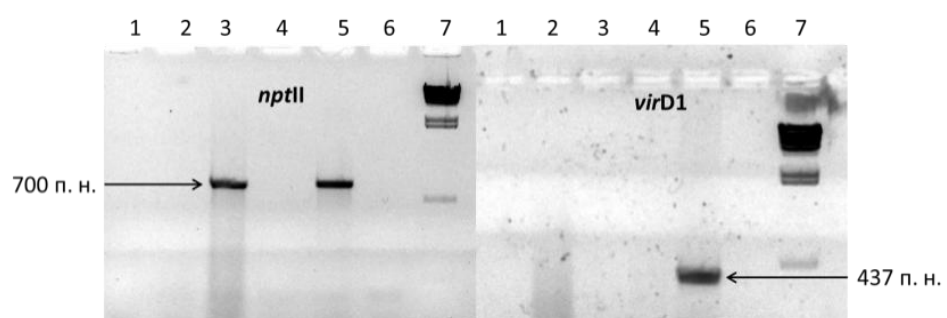

Fig. 5. Electrophoregrams of plant DNA amplification products of (PLS61) $\mathrm{R}_{2} \times \mathrm{PLS6} 6$ maize regenerants obtained by Agrobacterium-mediated transformation using vector pCB135 after PCR for the presence of the $n p t I I$ transgene and the bacterial vir-D1 gene. The expected fragment length for the nptII gene was 700 bp and for the vir-D1 gene - 437 bp. Lanes 1-7 - DNA samples: lane 1 - maize regenerant, line 14-1;2 - 6-5; 3 - 5; 4 - 8-4; 5 - positive control; 6 - negative control; 7 - DNA marker $\lambda /$ HindIII.

Interestingly, the signal intensity of amplicons corresponding to CP4epsps transgene, decreased as the regenerants were growing without selection pressure until complete disappearance in greenhouse plants (Fig. 4, lanes 1, 4, 5; lanes 3 and 7). Perhaps this was due to transgene methylation and, thus, a weaker affinity of DNA to the appropriate primers [18]. The maize genome has its native epsps gene, which can compete with the mutant transgene in the absence of selective pressure. In addition, a vector that did not contain nucleotide sequences of monocotyledonous plants to increase transgene expression in cereals was used in the study. These factors could lead to "knock out" of the transgene after removal of selective pressure as the unnecessary foreign genetic material.

Thus, we obtained transgenic maize regenerants containing the CP4epsps gene, after Agrobacterium-mediated transformation of the (PLS61)R $\mathrm{R}_{2} \times$ PLS61 morphogenic callus by pCB135 vector. The frequency of transformation was $1 \%$. In our view, the low transformation frequency of maize in this study compared to others [7] was caused by using a vector that did not contain regulatory sequences to enhance transgene expression in monocotyledonous plants.

\section{Conclusions}

We have identified the maize genotype $(\mathrm{PLS} 61) \mathrm{R}_{2} \times \mathrm{PLS} 61$, which is promising for studies on the genetic transformation of maize, due to the high regenerative potential of callus derived from immature embryos that remains for a long cultivation. Callus tissue obtained from immature embryos of the (PLS61) $\mathrm{R}_{2} \times \mathrm{PLS61}$ genotype, has a resistance to temporary agrobacterial contamination and the ability to retain its regenerative potential after glyphosate selection, which makes it particularly attractive for biotechnology studies to produce glyphosate-resistant maize plants. The use of maize morphogenic callus (PLS61) $\mathrm{R}_{2} \times$ PLS61 and glyphosate at a concentration of $0.1 \mathrm{mM}$ and $0.25 \mathrm{mM}$ in media for callusogenesis and $0.01 \mathrm{mM}$ in regeneration medium as a selective agent proved effective for the selection of transgenic plants with the CP4epsps gene after Agrobacterium-mediated callus transformation.

This work was supported by the Project 0115 U004187 "Using Molecular and Cellular Technologies for Biotech Wheat and Maize Plants Resistant to the Herbicide Glyphosate Obtaining" of the Target Comprehensive Interdisciplinary Scientific Research Program of the National Academy of Sciences of Ukraine "Molecular and Cellular Biotechnologies for the Needs of Medicine, Industry and Agriculture" and by the Project 0116 U001246 "Development of the Fundamental Basics of Molecular Genetic and Cellular Biotechnologies for Breeding Maize Improvement" of the Scientific Research Program "Biotechnology and Genetics in Plant Production" of the National Academy Agrarian Sciences of Ukraine.

\section{References}

1. Qamar Z., Aaliya K., Nasir I.A., Farooq A.M., Tabassum B., Ali Q., Ali A., Awan M.F., Tariq M., Husnain T. An overview of genetic transformation of glyphosate resistant gene in Zea mays. Nature and Science. 2015. Vol. 13, No. 3, P. 80-90. http://www.sciencepub.net/nature.

2. Karimi Y., Prasher S.O., Patel R.M., Kim S.H. Application of support vector machine technology for weed and nitrogen stress detection in corn. Computers and Electronics in Agriculture. 2006. Vol. 51, P. 99-109. DOI: 10.1016/j.compag.2005.12.001

3. Amrhein N., Deus B., Gehrke P., Steinrücken H.C. The site of the inhibition of the shikimate pathway by glyphosate, II: interference of glyphosate with chorismate formation in vivo and in vitro. Plant Physiol. 1980. Vol. 66, No. 5. P. 830-834.

4. ISAAA. Global status of commercialized biotech/GM crops in 2017: Biotech crop adoption surges as economic benefits accumulate in 22 years. Ithaca, NY: The International Service for the Acquisition of Agri-biotech Applications. 2018. http://www.isaaa.org/resources/publications/briefs/53/download/isaaa-brief-53-2017.pdf. 
5. Zhou H., Arrowsmith J.W., Fromm M.E., Hironaka C.M., Taylor M.L., Rodriguez D., Pajeau M.E., Brown S.M., Santino C.G., Fry J.E. Glyphosate-tolerant CP4 and GOX genes as a selectable marker in wheat transformation. Plant Cell Rep. 1995. Vol. 15. P. 159-163.

6. Howe A.R., Gasser Ch.S., Brown Sh.M., Padgette S.R., Hart J., Parker G.B., Fromm M.E., Armstrong Ch.L. Glyphosate as a selective agent for the production of fertile transgenic maize (Zea mays L.) plants. Molecular Breeding. 2002. Vol. 10, P. 153164.

7. Yadava P., Abhishek A., Singh R., Singh I., Kaul T., Pattanayak A., Agrawal P.K. Advances in maize transformation technologies and development of transgenic maize. Front Plant Sci. 2017. Vol. 7. P. 1-12. doi: 10.3389/fpls.2016.01949.

8. Kishore G.M., Padgette S.R., Fraley R.T. History of herbicide-tolerant crops, methods of development and current state of the art-emphasis on glyphosate tolerance. Weed Technol. 1992. Vol. 6. P. 626-634. http://www.jstor.org/stable/3987224.

9. Sidorov V., Duncan D. Agrobacterium-mediated maize transformation: immature embrious versus callus. Methods in Molecular Biology: Transgenic Maize. M. Paul Scott (ed.). USA: Humana press, 2009. P. 47-58.

10. Forlani G., Racchi M.L. Glyphosate tolerance in maize (Zea mays L.). Differential response among inbred lines. Euphytica. 1995. Vol. 82. P. 157-164.

11. Nitovska I.O., Abraimova O.Ye., Duplij V.P., Derkach K.V., Satarova T.M., Rudas V.A., Cherchel V.Yu. Dziubetskyi B.V., Morgun B.V. Application of beta-glucuronidase transient expression for selection of maize genotypes competent for genetic transformation. Cytology and Genetics. 2019. Vol. 53, No. 6. P. 451-458. doi: 10.3103/S0095452719060082.

12. Nitovska I.O., Komarnytsky I.K., Morgun B.V. Glyphosate selection of maize transgenic callus lines among genotypes of Ukrainian plant breeding. Fakt. Eksp. Evol. Org. 2017. Vol. 20. P. 237-242. [in Ukrainian] Нітовська I.О., Комарницький І.К., Моргун Б.В. Селекція на гліфосаті трансгенних калюсних ліній кукурудзи генотипів, районованих в Україні. Фактори експериментальної еволюиії організмів. 2017. Vol. 20. P. 237-242. URL: http://utgis.org.ua/journals/index.php/Faktory/issue/view/Faktory_V20_2017 (дата звернення: 5.03.2020).

13. Koncz C., Schell J. The promoter of $\mathrm{T}_{\mathrm{L}}$-DNA gene 5 controls the tissue-specific expression of chimaeric genes carried by a novel type of Agrobacterium binary vector. Mol. Gen. Genet. 1986. Vol. 204. P. 383-396.

14. Pescitelli S.M., Sukhapinda K. Stable transformation via electroporation in to maize Type II callus and regeneration of fertile transgenic plants. Plant Cell Rep. 1995. Vol. 14. P. 712-716. doi: 10.1007/BF00232653.

15. Murashige T., Skoog F. A Revised medium for rapid growth and bioassays with tobacco tissue culture. Physiol. Plant. 1962. Vol. 15. P. 473-497.

16. Stewart N.C. Jr., Laura E. Via a rapid CTAB DNA isolation technique useful for RAPD fingerprinting and other PCR application. BioTechnique. 1993. Vol. 14, No. 5. P. 748-749.

17. Derkach K.V., Abraimova O.E., Satarova T.M. Morphogenesis in vitro in maize inbred lines from the Lancaster heterotic group. Cytology and Genetics. 2017. Vol. 51, No. 1. P. 48-53. doi: 10.3103/S0095452717010030.

18. Matzke M.A., Mosher R.A. RNA-directed DNA methylation: an epigenetic pathway of increasing complexity. Nat. Rev. Genet. 2014. Vol. 15. P. 394-408. doi: 10.1038/nrg3683.

\section{НІТОВСЬКА I.O. ${ }^{1}$, МОРГУН Б.В. ${ }^{1}$, АБРАІМОВА О.Є. ${ }^{2}$, САТАРОВА Т.М. ${ }^{2}$}

${ }^{1}$ Інститут клітинної біологї та генетичної інженерії НАН України,

Україна, 03143, м. Київ, вул. Академіка Заболотного, 148, e-mail: iranit@ukr.net, molgen@icbge.org.ua

${ }^{2}$ Державна установа Інститут зернових культур НААН Украӥни,

Україна, 49600, м. Дніпро, вул. Володимира Вернадського, 14, e-mail: satarova2008@ukr.net

\section{СЕЛЕКЦІЯ НА СЕРЕДОВИЩАХ ІЗ ГЛІФОСАТОМ ТРАНСФОРМАНТІВ КУКУРУДЗИ 3 ГЕНОМ CP4EPSPS}

Mema. Дослідити умови селекції трансформантів кукурудзи, які б містили ген CP4epsps, з використанням гліфосату в якості селективного агенту. Методи. Культура тканин in vitro, Agrobacterium-опосередкована трансформація, селекція трансгенних рослин, виділення загальної ДНК рослин, аналіз рослинної ДНК методом полімеразної ланцюгової реакції (ПЛР). Результати. Продуковано морфогенний калюс кукурудзи з незрілих зародків гібрида (PLS61)R $2 \times$ PLS61, який має високу частоту регенерації (до 95\%), що зберігається впродовж тривалого культивування. В результаті Agrobacterium-опосередкованої трансформації морфогенного калюсу та селекції трансгенного матеріалу з використанням гліфосату були отримані трансформанти кукурудзи, які містили ген CP4epsps з частотою 1 \%. Висновки. Генотип кукурудзи (PLS61) $\mathrm{R}_{2} \times \mathrm{PLS61} \epsilon$ перспективним для досліджень з генетичної трансформації, зокрема отримання трансгенної кукурудзи, стійкої до гербіциду гліфосату. Використання морфогенного калюсу кукурудзи (PLS61)R $2 \times$ PLS61 та гліфосату в якості селективного агенту в концентрації 0,1 мМ та 0,25 мМ у середовищах для калюсогенезу і 0,01 мМ у середовищі для регенерації виявилось ефективним для відбору трансгенних рослин з геном CP4epsps.

Ключові слова: Zea mays L., морфогенний калюс, Agrobacterium-опосередкована трансформація, ПЛР, генетична інженерія. 